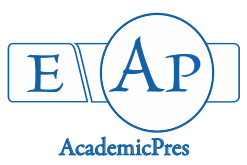

Mammen D (2021)

Notulae Scientia Biologicae

Volume 13, Issue 2, Article number 10872

DOI: $10.15835 / \mathrm{nsb} 13210872$

Research Article

\title{
Vincetoxicum indicum (Burm.f.) Mabb. - a case of transient abnormal secondary thickening in stem
}

\author{
Mammen DANIEL ${ }^{1}$, Denni MAMMEN ${ }^{2 *}$
}

\author{
${ }^{1}$ Dr. Daniel's Laboratories, 1st Floor, RutuPlatina, Manjalpur, Vadodara-390011, India; mdanieluni@gmail.com \\ ${ }^{2}$ Navrachana University, School of Science, Vasana Bhayli Road, Vadodara-391410, India; drdenni.mammen@gmail.com \\ ('corresponding author)
}

\begin{abstract}
Vincetoxicum indicum (Burm.f.) Mabb. (Syn. Tylophora indica(Burm.f.) Merr., T. asthmatica W. \&A.), an important twining medicinal plant of India, was found to show a transient anomalous secondary thickening to facilitate the twisting of stem around a support. The very young stem had a continuous primary xylem cylinder, the protoxylem of which differentiated to two large bundles on the opposing sides and many smaller bundles in between. In the initial stages of maturation, the cambium outside the two large protoxylem groups behaved abnormally in producing more phloem outwards and little or no secondary xylem inwards to produce two wedge shaped phloem groups on opposite sides. The production of crescent shaped secondary xylem on the other two sides which fell at a right-angled plane resulted in bulging of these sides away from the anomalous cambium to create a rectangular stem having two broad sides which were used as the facing sides of stem against a support. As soon as the twisting nature was established, the anomaly was reversed and the anomalous cambial patches started behaving normally to produce a complete ring of secondary xylem. As this abnormal behaviour happened only during the twisting of stem, this is considered as an adaptational anomalous secondary thickening.

Keywords: anomalous secondary thickening; phloem wedges; transient anomaly; Vincetoxicum indicum (Burm.f.) Mabb.
\end{abstract}

\section{Introduction}

Anomalous secondary thickenings are considered adaptational features meant for certain functions in abnormal conditions. These are changes in the structure of stem/root which enable the plant to adapt a twining habit or as in succulents to store more water and food in stems. The Caryophyllidae of Cronquist containing families like Amaranthaceaae, Chenopodiaceae, Nyctaginaceae, which normally inhabit arid regions of the world, is characterised by abnormal secondary thickening (Cronquist,1981; Kishore and Rao, 2000). The included phloem found in Chenopodiaceae is considered for preserving the phloem in active condition for many years. Even if the outer tissues of stem dry out during the long summer, the included phloem strands remain viable and so can supply nutrients to the buds which, at the onset of the favourable season, can commence development (Fahn and Shchori, 1967). The wedge-shaped phloem in Bignonia helps the plant stem to keep flexibility helping the stem to bend during the process of climbing. The flattened stem shape in 
lianas, which is an adaptation helping the stem to twist around a support, is due to cessation of cambial activity altogether with the production of large areas (Metcalfe and Chalk, 1950). In Tinospora, a twiner, very large and wide rays are produced due to the lack of interfascicular cambium during secondary thickening (Vidya and Nutan, 2018). But all these abnormalities are permanent and stay with the plant during the entire life. But here we report a transient type of abnormal secondary thickening in stem of a twining vine, Vincetoxicum indicum which disappears when the need for abnormality is over and the old stem remains devoid of any abnormality.

Vincetoxicum indicum (Burm.f.) Mabb. (Syn. Tylophora indica (Burm.f.) Merr., T. asthamatica W. \&A.) is a twiner of excellent medicinal properties and is much sought after for whooping cough, asthma and allergy (Daniel, 2006). It branches profusely and twines around any support be it another plant or a non-living support like ropes, rods etc. Most of the times, the young shoots intertwine among themselves or on older stems of the very same plant (Figure1A-D). During the pharmacognosy studies on this plant we have noticed, which we report here, wedge shaped phloem in young stems similar to that observed in species of Bignonia, which disappears in old stems.

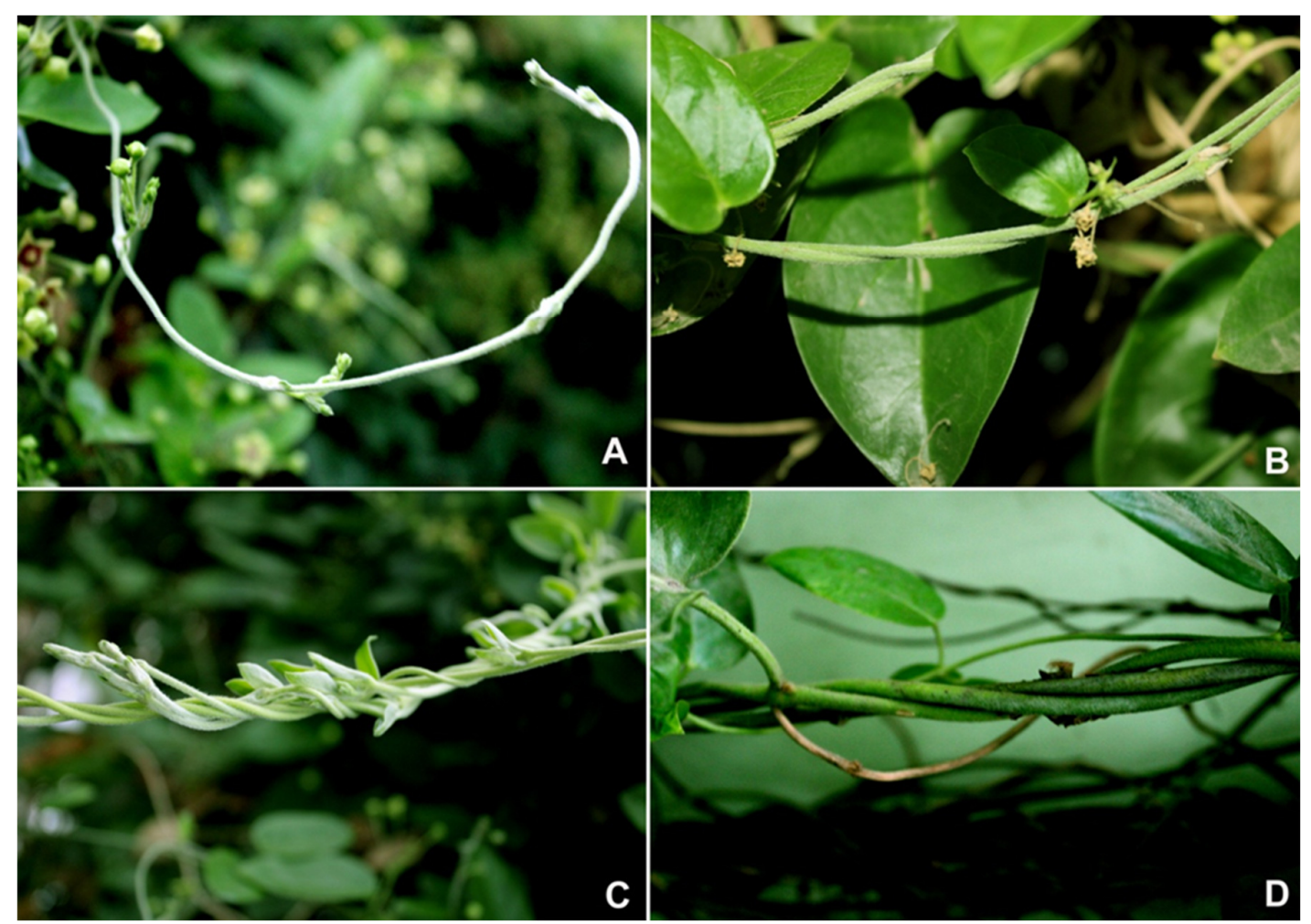

Figure 1. A. Juvenile stem showing first and second nodes. B. Two young stems intertwined C. Many young stems twining among themselves. D. Mature stems

\section{Materials and Methods}

Fresh plant materials were collected from Botanical garden of M.S. University of Baroda and compared with the Herbarium (BARO) in Department of Botany. Voucher specimen (D/1160) was deposited in Baroda University Herbarium. Fresh young as well as older stems were used for initial studies which involved hand sections. Later these stems collected were fixed in FAA (Johansen, 1940). They were embedded in paraffin and transverse sections were taken in a rotary microtome. Sections were selected and stained with safranin and after 
dehydration mounted in DPX.The sizes (dimensions) of various cells and crystals were measured using stage and ocular micrometers. The quantitative data are based on an average of 20 readings.

\section{Results}

Very young stem near apex, below first node

The tender stem was circular in outline with very little mechanical tissues. All the tissues were at differentiating stages (Figure 2A). A tender stele was observed encircling the pith. The vascular tissues formed continuous rings and in the developmental stage consisted of an inner ring of primary xylem and outer ring of primary phloem. The protoxylem components of xylem positioned towards centre of stem were seen organised to many bundles, having arrays of protoxylem, of which two were large and 8-10 were small. The two large bundles were seen positioned on opposing sides and the remaining small groups formed two sets of 3-4 small bundles, each on either side, in between the large bundles. The large groups of protoxylem (Figure 2B) consisted of about 8-10 rows of tracheids towards the centre which are in line with radial rows of larger cells representing metaxylem positioned towards periphery. Each row of protoxylem consisted of 2-3 tracheids, the smallest towards the pith and larger to cortex. The colourless cells of metaxylem which formed a continuous ring around the pith, were differentiated to alternate uniseriate radial rows of large square cells (corresponding to tracheids) in line with rows of protoxylem, with alternate rows of smaller parenchyma cells, which corresponded to rays (Figure 2C). The smaller bundles of protoxylem consisted of 1-3 radial rows of tracheids in line with corresponding metaxylem cells. Inner to protoxylem were internal phloem groups seen in patches at the periphery of pith. Outer to the xylem region was a continuous ring of phloem represented by 2-3 layers of soft tissues. Pith contained isodiametric large parenchyma cells. The cortex was differentiated to three regions, innermost 1-2 layers of chlorenchyma, middle region with round/oval patches of developing gelatinous fibres (Figure 2E) separated by chlorenchyma and outer 3-4 layers of parenchyma (Figure 2D). Epidermis consisted of barrel shaped cells with hypodermis formed of an outer layer of colourless parenchyma cells and inner 2-3 layered chlorenchyma rich in chloroplasts (Figure 2D, F). There were multicellular uniseriate 2-3 celled trichomes on the epidermis (Figure 2F, G).

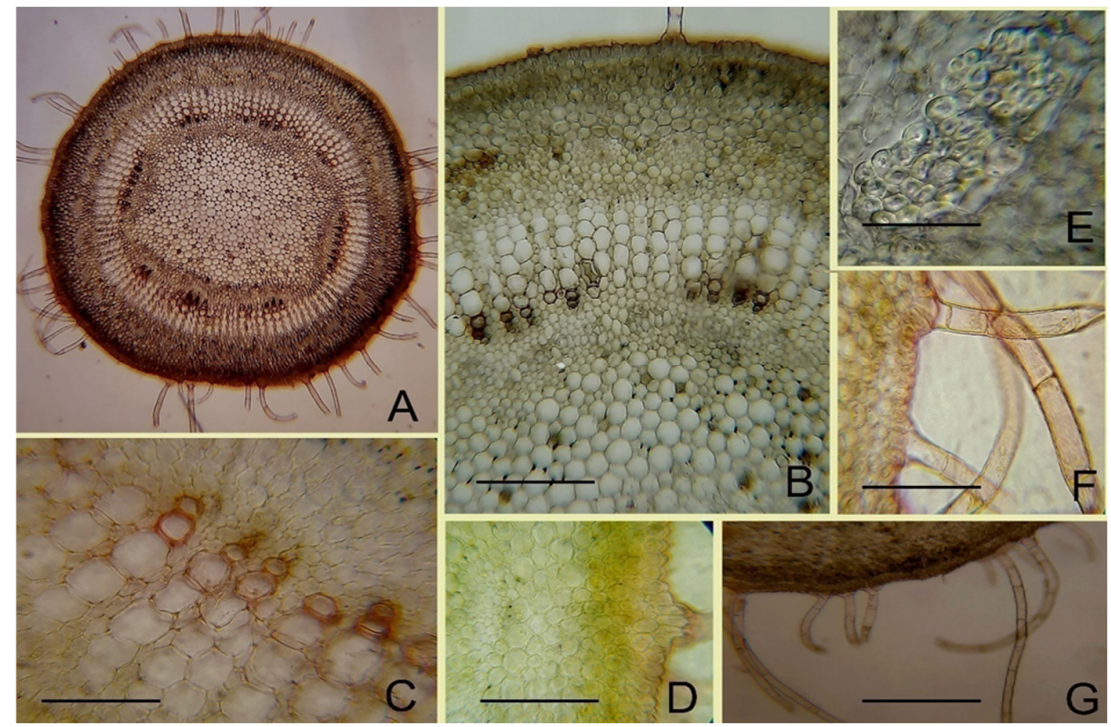

Figure 2. A. Very young stem, B. Portion showing the large conglomerate of protoxylem, C. Square metaxylem cells alternating with ray initials, D. Cortex, hypodermis and epidermis, E. Cortex with developing gelatinous fibres F. Hypodermis of chlorenchyma, G. Multicellular uniseriate trichomes. Scale bar: $400 \mu(\mathrm{B}, \mathrm{G})$, and $100 \mu(\mathrm{C}, \mathrm{D}, \mathrm{E}, \mathrm{F})$ 


\section{Young stem as seen in the second internode}

The main development observed here was the visible lignification of the metaxylem to a continuous ring of almost rectangular tracheids (Figure 3A, B, E). Associated with this was the lignification of gelatinous fibers in cortex (Figure 3C) as well as of parenchymatous pith cells (Figure 3B). The inner phloem also got distinguished from adjoining cells (Figure 2D). At the second internode, the stem started coiling around a support and secondary thickening got initiated.

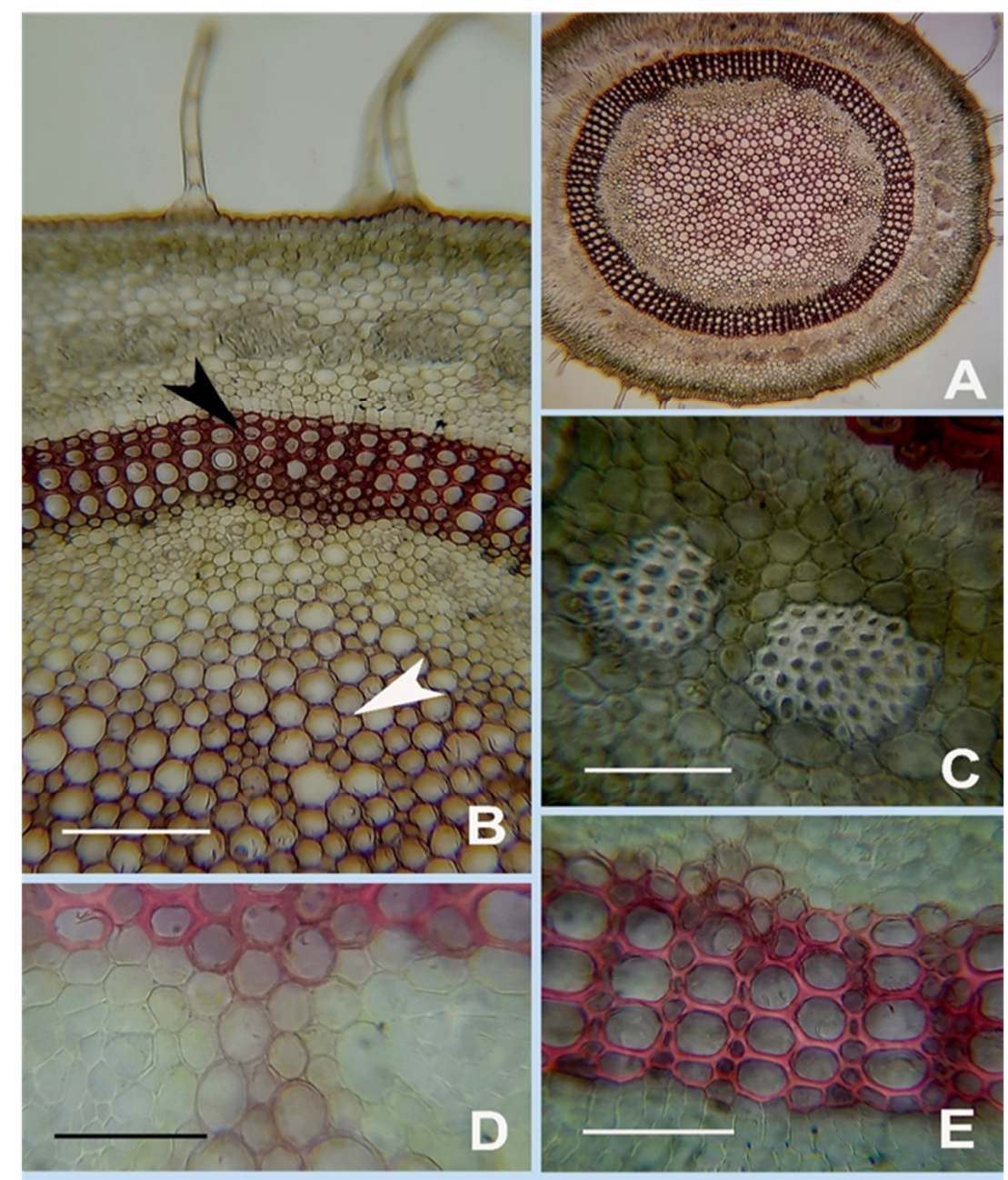

Figure 3. A. Lignification of cells in stem of second internode. B. Lignified metaxylem tracheids with ray cells (Black arrow) and lignified pith (White arrow), C. Cortical gelatinous fibres getting lignified. D. Inner phloem developing, E. Close up of Metaxylem. Scale bar: $400 \mu$ (B), and 100 $($ C, D, E)

\section{Secondary thickening from third internode onwards}

As the primary xylem occurred as a continuous patch, there was no development of interfascicular cambium. Fascicular cambium behaved normally, except for the region of two large groups of protoxylem bundles occurring at opposite places, producing secondary xylem inwards and secondary phloem outwards. In the region outside the two large protoxylem groups, cambium behaved abnormally by producing only phloem outside and which later lead to two wedge shaped secondary phloem incursions (4D) at opposite sides (Figure 4A). Secondary xylem formed due to the normal cambium (at right angles to abnormal cambium) appeared as two concave patches at the opposite plane which grew bigger in course of time. The large amount of xylem produced at these two sides caused the broadening of stem sideways. The absence of secondary xylem at the 
right-angled plane (where wedge shaped phloem was the only secondary tissue) resulted in formation of a rectangular shaped stem (Figure 3B) as seen in stems of Bauhinia glabra (Fisher and Blanco, 2014). Crystal formation of calcium oxalate in cortex also get initiated at this stage (Figure 4E).

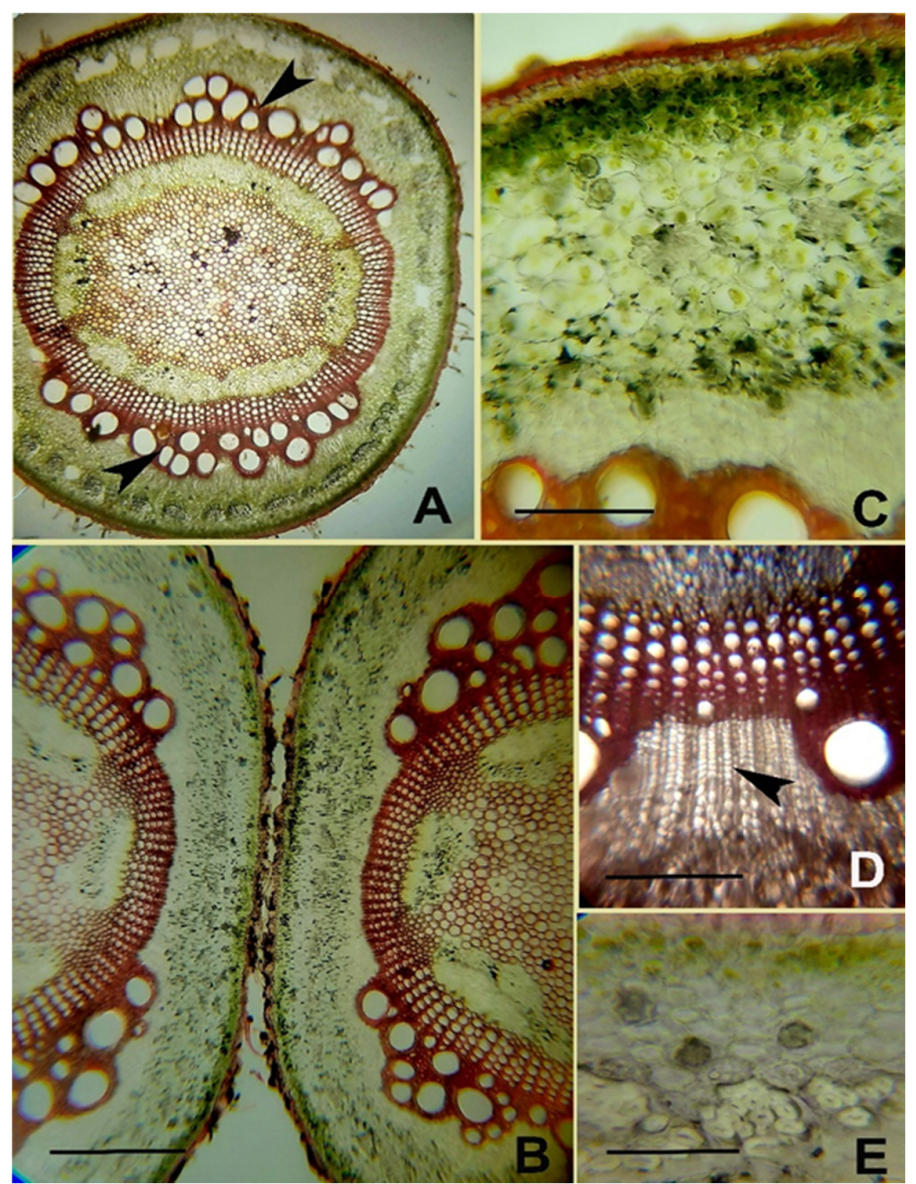

Figure 4. A. Abnormally behaving patches of cambium at opposite sides (white arrow) and normal cambial cells producing secondary xylem towards inside (Black arrow), B. Stem developing rectangular shape and parallelly placed sister branches coming closer for twining at their broader sides, C. Wavy outline of secondary xylem and vessel bordering the phloem wedge. D. Wedge shaped secondary phloem, E. Inner cortex with gelatinous fibres and crystals of Calcium oxalate. Scale bar: $400 \mu(\mathrm{B})$, and $100 \mu(\mathrm{C}, \mathrm{D}, \mathrm{E})$

As the stem started twining from the second node onwards around its own sister branches, the broader side of stem (where the secondary xylem was not produced) was found facing similar sides of other branches and these branches are seen adhering to each other. The broad sides, evidently, gave more surface of interaction between twining branches (Figure 4C). Therefore, it appears this anomaly is a feature adapted by the plant to give more flexibility to coil around.

As the stem matures, the two regions of anomalous cambia continued producing phloem towards outside resulting in the formation of two larger wedge-shaped secondary phloem incursions on the broader side of stem (Figure 4B), while the normal xylem produced more secondary xylem towards the narrow side of stem. The outline of secondary xylem was not uniform as in normal dicotyledonous stem, but appeared wavy due to the bulging of sec. xylem, especially the large vessels, into the cortex (Figure 4C). The vessels in secondary xylem were very large reaching a diameter of about $120 \mu$ surrounded by tracheids (a few) and fibers (14-18 $\mu$ ), The tracheids in primary xylem were much larger (about $40 \mu$ ). In few samples the two vessels bordering the wedges of phloem were distinctly stained red (Figure 4C). 
The secondary thickening occurring after the stem finished active coiling (as coiling takes place in the initial stages of growth) is very interesting. As the flexibility was not needed further and the stem needed to acquire more mechanical strength, the abnormality adapted in young stem was reversed to make the mature stem hard and strong. In this process the wedges (of phloem) got filled up with secondary xylem and a continuous ring of secondary xylem resulted. This process of reversing the abnormality started with the production of secondary xylem (mostly tracheids) inwards by the same cambial cells which were earlier found cutting off sec. phloem outwards (Figure 5A- arrows). As this activity progressed, the production of secondary phloem towards outside was completely stopped and more of secondary xylem, including large vessels were produced inwards. This continued till the outer layers of nascent xylem attained the levels of the xylem produced by normal cambium, and then both the normal cambia and abnormal cambia joined to form a ring around the stem, and the wedges (of phloem) disappeared completely (Figure 5B) and the stem retained its round shape. The elastic gelatinous fibres also are found shrinking (Figure 5E.) At maturity there remained absolutely no trace of abnormality in secondary thickening.
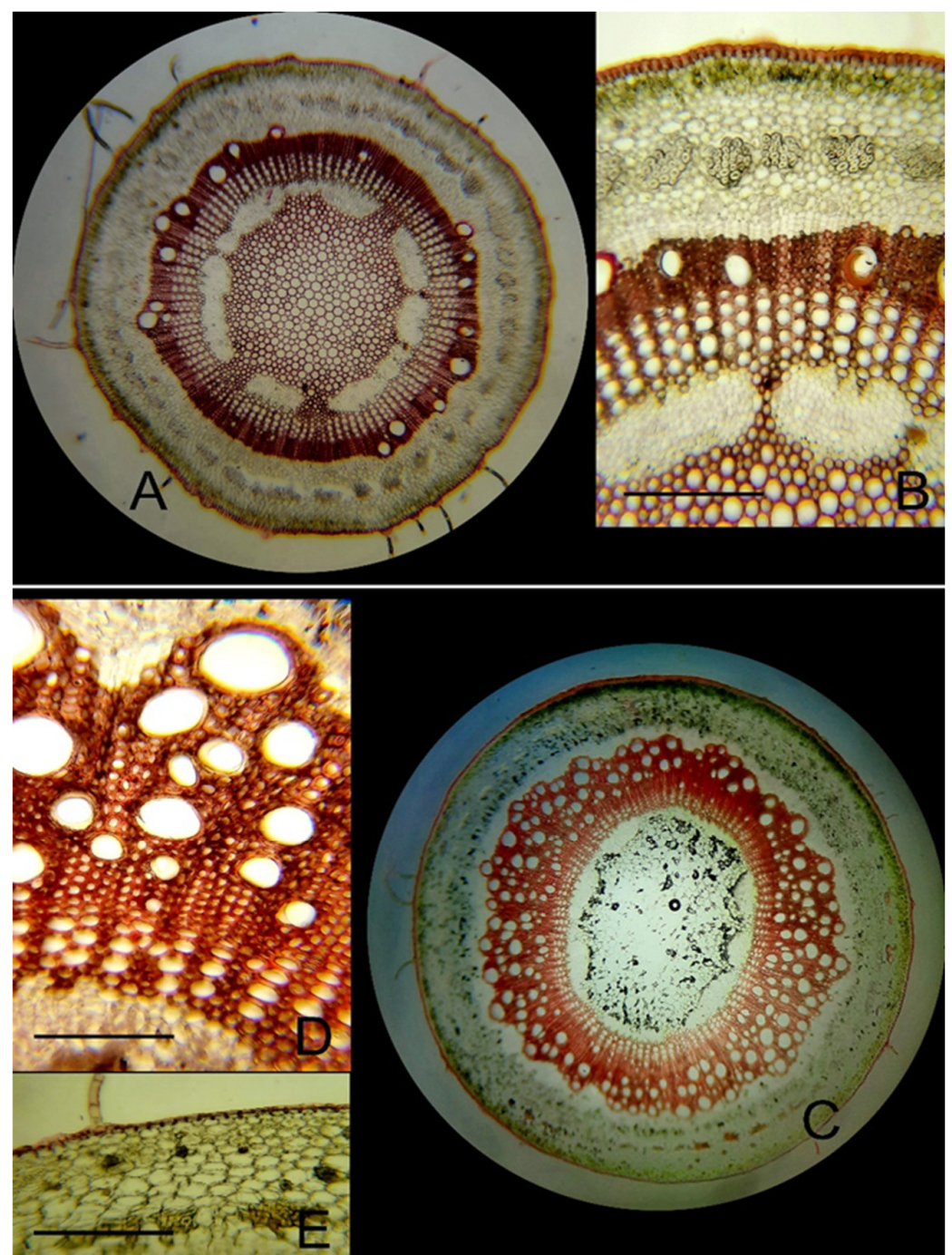

Figure 5.A. Abnormally behaving cambium below phloem wedges producing secondary xylem tracheids towards inner side, B. Close up of secondary xylem beginning to fill the wedges. C. Mature stem with round outline and no sign of abnormality. D. Close up of wedges completely filled in by Sec. Xylem. E. Collapsing of gelatinous fibres upon maturity of stem. Scale bar: $400 \mu$ (B), and $100 \mu$ (D, E) 


\section{Discussion}

Vincetoxicum indicum (Burm.f.) Mabb. is a stem twiner which coils around any support, organic (other plants) or inorganic. Many a times the slender tip of a stem is found coiling around other tender stems or mature stems of the very same plant. For this purpose, the stem should be flexible allowing it to wind and coil around.

Some of the twiners like Tinospora have their central vascular cylinder split to many similar units due to development of very large and wide medullary rays (Vidya and Nutan, 2018) or have wedge shaped phloem incursions as in Bignonia which give the flexibility to the stem to twist around a support (Pace and Angyalossy, 2013). In cases of vines of Bauhinia, the stem becomes ribbon shaped due to increased activity of two patches of cambium on opposite sides, while the regions at right angles produce very fewer secondary tissues (Fisher and Blanco, 2014). But in the case of Vincetoxicum it is a combination of the anomalies found in Bignonia and Bauhinia, because except for two opposing regions the cambial activity is normal and the abnormal activity of cambial patches at right angles produce wedge shaped phloem incursions. The stem changes its outline from round (in very young stem) to rectangular (in mature stems) so that it can twist around the support using the broad side for adhering. But the anomaly does not cease there. As soon as the need for a support is accomplished, the coiled stem matures by addition of more secondary xylem on both sides where there was no secondary xylem. As this mature stem need not be flexible any more, the anomaly gets reversed by the return of normal behaviour of the cambia opposite the wedges (which produced more phloem and little xylem earlier) to produce xylem towards inside and less phloem outside. The previous abnormal behaviour of cambium ends and the very same cambium produces more xylem towards inside and little or no phloem outside. This results in gradual pushing out of cambium by the nascent xylem mass. This continues till this ring of cambium reaches the level of normal cambium where both the cambial layers join to form a continuous layer producing xylem towards inside and phloem towards outside. In this process another anomaly seen is the inactivity of cambium towards outside where, otherwise it has to produce phloem. In a very mature stem, there is no sign of abnormality in secondary thickening.

A second abnormality seen here is the continuous cylinder of primary vascular tissues in young stems. Normally the primary xylem in dicotyledonous plants consists of a split stele in which separate vascular bundles make up a vascular cylinder wherein the conjunctive tissue (from which the interfascicular cambium develop) separates individual vascular bundles from each other. Here the separate protoxylem groups indicate presence of individual vascular bundles but the metaxylem and phloem outside form a continuous ring, which is an unusual feature otherwise commonly seen in siphonaceous stele of some Pteridophytes like Osmunda, Schizaea etc. (Eames, 1936).

Another puzzling question is how the plant comes to know when to start twisting the stem so that it winds around another support. The tender primary xylem, with non-lignified xylem tracheids, allows the flexibility and immediately (in the second internode itself) the abnormality get started by stopping the production of hard tissues (here lignified xylem tracheids and vessels) at the region of contact so that the stem outline becomes rectangular to facilitate more area on the surface of contact. Another question is how the plant recognises the time to stop the abnormality and revert back to pre-abnormal conditions. Can we connect all these to the native "intelligence of plants" (Daniel, 2009) or is it a chance?

\section{Conclusions}

Vincetoxicum indicum (Burm.f.) Mabb., an important twining medicinal plant of India, was found to show a transient anomalous secondary thickening to facilitate the twisting of stem around a support. The very young stem had a continuous primary xylem cylinder, the protoxylem differentiated to two large bundles on the opposing sides and many smaller bundles in between. In the initial stages of maturation, the cambium outside the two large vascular bundles behaved abnormally in producing more phloem outside and little or no 
secondary xylem inside to produce two wedge shaped phloem incursions on opposite sides. The production of secondary xylem on the other two sides which fell at a right-angled plane resulted in bulging of these sides away from anomaly to create a rectangular stem having two broad sides which were used as the facing sides of stem against a support. As soon as the twisting nature was established, the anomaly is reversed and the anomalous cambial patches started behaving normally to produce a complete ring of secondary xylem. As this abnormal behaviour happened only during the twisting of stem, this is considered as an adaptational anomalous secondary thickening.

\section{Authors' Contributions}

The research work was conceptualized and sectioning performed by MD. The description and initial draft of the manuscript was prepared by MD. The photography and preparation of the photo plates and final draft of the manuscript was done by DM.

Both authors read and approved the final manuscript.

\section{Acknowledgements}

This research received no specific grant from any funding agency in the public, commercial, or not-forprofit sectors.

\section{Conflict of Interests}

The authors declare that there are no conflicts of interest related to this article.

\section{References}

Cronquist A (1981). An Integrated system of classification of flowering plants. Columbia University Press, New York. Daniel M (2006). Medicinal plants: chemistry and properties. Science Publishers, New Hampshire, USA.

Daniel M (2009). Taxonomy: Evolution at work. Alpha Science International Ltd, Oxford, UK.

Eames AJ (1936). Morphology of vascular plants, lower groups. McGraw Hill, New York.

Fahn A, Shchori Y (1967). The organization of the secondary conducting tissues in some species of the Chenopodiaceae. Phytomorphology 17:147-154.

Fisher JB and Blanco MA (2014). Gelatinous fibers and variant secondary growth related to stem undulation and contraction in a monkey ladder vine, Bauhinia glabra (Fabaceae). American Journal of Botany 101(4):608-616. https://doi.org/10.3732/ajb.1300407

Johansen DA (1940). Plant microtechnique. McGraw Hill, NewYork.

Kishore SR, Rao KS (2000) Secondary growth in the stem of some species of Alternanthera and Achyranthes aspera (Amaranthaceae). IAWA Journal 21(4):417-424. https://doi.org/10.1163/22941932-90000257

Metcalfe CR, Chalk L (1950). Anatomy of the dicotyledons. Clarendon Press, Oxford.

PaceMR, Angyalossy V (2013). Wood anatomy and evolution: a case study in the Bignoniaceae. International Journal of Plant Sciences 174:1014-1048. https://doi.org/10.1086/670258

Vidya SP, Nutan PM (2018). Development of xylem plates and stem anatomy of Tinospora cordifolia(Willd.) Miers. (Menispermaceae). Thaiszia Journal of Botany 28(1):07-17. 
OPEN ACCESS

(c) (2)

The journal offers free, immediate, and unrestricted access to peer-reviewed research and scholarly work. Users are allowed to read, download, copy, distribute, print, search, or link to the full texts of the articles, or use them for any other lawful purpose, without asking prior permission from the publisher or the author.

License - Articles published in Notulae Scientia Biologicae are Open-Access, distributed under the terms and conditions of the Creative Commons Attribution (CC BY 4.0) License.

(C) Articles by the authors; SHST, Cluj-Napoca, Romania. The journal allows the author(s) to hold the copyright/to retain publishing rights without restriction. 